\title{
Analisis Faktor-Faktor yang Dapat Mempengaruhi Pengentasan Kemiskinan di Indonesia (2016-2019)
}

\author{
Bariyyatin Nafi'ah \\ Magistes Sains Ekonomi Islam Universitas Airlangga \\ Email korespondensi: bariyyatinnafiah13@gmail.com
}

\begin{abstract}
Penelitian ini bertujuan untuk menganalisis Zakat, Infaq, Shadaqah, Indeks Penbangunan Manusia(IPM), Inflasi terhadap pengentasan Kemiskinan di Indonesia (periode Tahun 2016-2019). Data yang digunakan pada penelitian ini adalah data sekunder dan metode yang digunakan yaitu analisis regresi data panel menggunakan Random Effect Model dengan bentuan program Eviews 9 untuk memperoleh gambaran antar satu variabel dengan variabel yang lainnya. Penelitian ini terdiri dari 34 Provensi yang ada di indonesia selama 4 tahun yakni dari tahun 2016- 2019. Hasil penelitian ini menunjukkan bahwa variabel ZIS memiliki pengaruh terhadap pengentasan kemiskinan sedangkan IPM dan Inflasi tidak perpengaruh signifikan terhadap pengentasan Kemiskinan. Berdasarkan pada hasil regresi dengan menggunakan rendom effect mode yang terlihat pada tabel, diketahui bahwa nilai koefisien determinasi sebesar 0,679005 memiliki arti bahwa ZIS, IPM dan Inflasi berpengaruh terhadap tingkat kemiskinan sebesar 67, $9 \%$. Sedangkan sisanya 30,3\% dipengaruhi oleh hal yang lain yang tidak di analisis pada penelitian ini.
\end{abstract}

Kata Kunci : Kemiskinan, Zakat Infaq Shadaqah (ZIS), Indeks Pembangunan Manusia (IPM) dan inflasi.

\begin{abstract}
This study aims to analyze Zakat, Infaq, Sadaqah, Human Development Index (HDI), Inflation on poverty alleviation in Indonesia (2016-2019 period). The data used in this study are secondary data and the method used is panel data regression analysis using the Random Effect Model with the form of the Eviews 9 program to obtain an overview between one variable and another. This study consists of 34 proventions in Indonesia for 4 years, from 2016 to 2019. The results of this study indicate that the ZIS variable has an influence on poverty alleviation while HDI and inflation have no significant effect on poverty alleviation. Based on the regression results using the rendom effect mode shown in the table, it is known that the coefficient of determination of 0.679005 means that ZIS, HDI and inflation have an effect on the poverty rate by $67.9 \%$. While the remaining $30.3 \%$ is influenced by other things that are not analyzed in this study.
\end{abstract}

Keyword: Poverty, Zakat Infaq Sadaqah (ZIS), Human Development Index (HDI) and inflation.

Saran sitasi: Nafi'ah, B. (2021). Analisis Faktor-Faktor yang Dapat Mempengaruhi Pengentasan Kemiskinan di Indonesia (2016-2019). Jurnal Ilmiah Ekonomi Islam, 7(02), 953-960. doi:http://dx.doi.org/10.29040/jiei.v7i2.2206

DOI: http://dx.doi.org/10.29040/jiei.v7i2.2206

\section{PENDAHULUAN}

Pertumbuhan ekonomi dan kemiskinan merupakan suatu indikator yang penting untuk dapat melihat keberhasilan pembangunan suatu negara. Setiap negara akan selalu bekeja keras agar dapat mencapai pertumbuhan ekonomi yang optimal dan menurunkan angka kemiskinan. Setiap negara diseluruh negara syarat utama bagi terciptanya penurunan angka kemiskinan ialah dengan pertumbuhan ekonomi. Namun, kondisi di negaranegara yang berkembang termasuk di Indonesia pertumbuhan ekonomi yang dicapai ternyata juga diiringi dengan munculnya permasalahan meningkatnya jumlah penduduk yang hidup dibawah garis kemiskinan.

Kemiskinan merupakan salah satu masalah yang selalu dihadapi oleh manuisa. Masalah kemiskinan itu sama tuanya dengan usia kemusiaan 
itu sendiri dengan usia kemanusiaan itu sendiri dan implikasi permasalahannya dapat melibatkan keseluruhan aspek kehidupan manusia, meskipun seringkalai kehadirannya tidak disadari sebagai suatu masalah untuk sebagian manusia yang bersangkutan. Bagi mereka yang tergolong miskin, kemiskinan merupakan suatu yang nyata ada dalam kehidupan mereka sehari-hari, karena mereka itu merasakan dan menjalani sendiri bagaimana mereka hidup dalam kemiskinan. Secara siangkat kemiskinan itu dapat disefinisikan sebagai suatu standar tingkat hidup yang rendah, yaitu adanya suatu tingkat kekurangan materi pada sejumlah atau segolongan orang dibandingkan dengan standar kehidupan yang umum berlaku dalam masyarakat yang bersangkutan.

Permasalahan kemiskinan merupakan suatu permasalahan yang masih dihadapi oleh seluh bangsa didunia, terutama di Negara-negara yang masih seperti Indonesia. Kemiskinan sendiri merupakan suatu permasalahan sosial yang sangat kompleks dan banyak faktor-faktor yang menjadi aspek dari penyebab kemiskinan pada suatu negara. Salah satunya adalah kurangnya pendapatan karena sulit mendapatkan pekerjaan, pendidikan, kesehatan dan ketimpangan. Kemiskinan dapat diartikan dimana seseorang tidak mampu memenuhi kebutuhan kehidupan dasarnya seperti halnya makanan, pakian, tempat tinggal, tingkat kesehatan dan pendidikan.

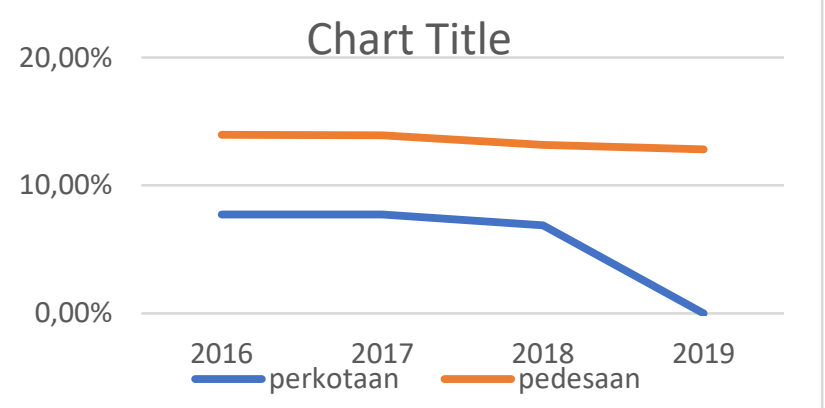

\section{Gambar.1 Kemiskinan indonesia 2016-2019}

Tabel diatas menunjukkan bahwa pada setiap tahunnya dari 2016- 2019 angka kemiskinan di indonesia baik di perkotaan atau pun di pedesaan mengalami penurunan pada setiap tahunnya. Hal tersebut tentunya merupakan suatu hal yang baik untuk negara Indonesia.

Pemerintah indonesia menyadari bahwa pembangunan nasional merupakan salah satu upaya untuk menjadi tujuan masyarakat adil dan makur. Sejalan dengan tujuan tersebut, maka berbagai kegiatan pembangunan telah diarahkan kepada pembangunan daerah khususnya daerah yang relatif mempunyai kemiskinan yang terus naik dari tahun ketahun. Dalam mengurangi kemiskinan, pemerintah telah menggulirkan berbagi bentuan atau isentif berupa dana maupun program, seperti halnya program penanggulangan kemiskinan dan perkotaan (P2KP), bantuan beras untuk rakyat miskin (Raskin), program Nasional pemberdayaan Masyarakat Mandiri (PNPM) dan bantuan lainnya. Namun demikian, upaya tersebut tidak dapat memberikan suatu dampak yang berbarti karena insentif seperti BLT hanya bersifat konsumtif dan sebagai suatu kenikmatan sesaat sehingga akan mengakibatkan ketergantungan masyarakat miskin terhadap bantuan padahal harapan dari adanya program tersebut tidaklah demikian Indonesia merupakan suatu negara yang berkembang yang memiliki jumlah penduduk mayoritas Islam terbesar di dunia (Al Anshori, 2017)

Dalam pembangunan modern Indeks Pembangunan Manusia berperan penting sebab pembangunan manusia yang baik tentuanya akan menjadikan faktor-faktor produksi mampu untuk dimaksimalkan. Pendidikan yang baik akan mampu untuk berinovasi mengembangkan faktor-faktor produksi yang ada. Selain itu pembangunan manusia yang tinggi akan mengankibatkan jumlah penduduk akan tinggi pula sehingga akan menaikkan tinkat konsusmi. Maka dalam hal ini tentnya juga akan mempermudah untuk menggalakkan pertumbuhan ekonomi (Sukirno 2013).

Inflasi ialah salah satu indikator yang penting untuk pengendaian ekonomi makro yang tentunya berdampak luas kepada berbagai sektor ekonomi. Dengan syarat dan batas-batas yang masih toleran dengan adanya inflasi akan mendorong perekonomian.

Tidak hanya pada sisi ekonomi seperti halnya inflasi, dalam segi agama juga terdapat Zakat, Infaq dan shadaqah (ZIS) dimana zakat sendiri memiliki peran yang sangat strategis dalam upaya untuk pengentasan kemiskinan atau pembangunan ekonomi. Pertumbuhan zakat merupakan salah satu paradigma dalam kerangka islam (Khoute \& Khouloud. 2020). Indonesia memiliki potensi yang besar dalam penghimpunan dana zakat. Demografi Indonesia yang mayoritas penduduknya beragama Islam merupakan kondisi yang memberikan peluang besar untuk mengembangkan dan mengelola dana zakat tersebut. ( Ridwan, Laila. 2019). Begitu halnya dengan infaq dan shodaqah. Maka dari uraian diatas dalam penelitian ini peneliti mengambil penelitian yang akan berjudul 


\section{Jurnal Ilmiah Ekonomi Islam, 7(02), 2021, 955}

"ANALISIS FAKTOR-FAKTOR YANG DAPAT MEMPENGARUHI

PENGENTASAN

KEMISKINAN DI INDONESIA (2016- 2019)"

\section{KAJIAN TEORI}

\section{Kemiskinan}

Kemiskinan menurut Badan Statistik merupakan ketidakmampuan memenuhi standar minimum kebutuhan dasar yang meliputi kebutuhan makan maupun non makan. Kemiskinan jika dilihat dari ketimpangan sosial, karena ada orang yang telah dapat memenuhi kebutuhan dasar minimumnya akan tetapi masih jauh lebih rendah dibandingkan dengan masyarakat disekitarnya (lingkungannya). Semakin besar ketimpangan pendapatan antara golongan atas dan golongan dibawah maka akan semakin banyak jumlah penduduk yang dikatagorukan sebagai penduduk miskin, sehingga kemiskinan akan relatif erat hubungannya dengan masalah distribusi pendapatan.

Faisal Basri mengemukakan bahwa salah salah satu prasyarat dari keberhasilan pada programprogram pembangunan sangat tergantung pada ketepatan pengidentifikasian pada target area dan tanrget group. Dalam pelaksanaan perogram pengentasan nasib orang miskian, keberhasilanya yakni bergantung kepafa langkah awal dari formuslasi kebijakan, yakni mengindentifikasi siapa yang sebenarnya si "miskin" tersbeut dan dimana ia berada. Maka dengan memperhatikan prifil pada kemiksinan, diharapkan kebijakan yang disususn dalam mengentaskan orang miskin akan lebih terarah dan lebih tepat sasaran. Demikian pula, akan dapat dievalusi apakah kebijakan-kebijakan pemerintah yang diaplikasikan selama ini dapat mendukung atau malah bertentangan dengan usaha dalam mengurangi jumlah penduduk miskin (Basri, 1995: 178).

Kemiskinan dalam artian luas merupakan sebagai keterbatasan yang disandang oleh seseorang, sebab sebuah karya, sebuah komunitas atau bahkan sebuah negara yang menyebabkan terjadinya ketidaknyamanan dalam suatu kehidupan, terancamnya hal keadilan, terancamnya posisi tawar (bargaining) dalam pergaulan dunia dan pada jangka yang lebih panjang akan dapat mengakibatkan hilangnya generasi, serta suramnya masa depan bangsa dan negara. Negara-negara maju dalam mengukur tingkat pertumbuhan ekonominya adalah lebih menekankan pada keualitas hidup yang dinyatakan dengan suatu perubahan lingkungan hidup.
Menurut Tadoro (1994) menyatakan bahwa variasi kemiskinan di negara yang berkembang disebabkan oleh antara lain: 1) perbedaan geografis, jumlah penduduk dan tingkat pendapatan 2) perbedaan sejarah, dimana dalam hal ini sebagian dijajah oleh Negara yang berlainan. 3) perbedaan kekayaan sumber daya alam dan kualitas sumber daya manusiaya, 4) perebedaan peranan sektor swasta dan Negara 5) perbedaan struktur industrinya: 6) perbedaan derajat ketergantungan pada kekuatan ekonomi dan politik negara lain dan 7) perbedaan pebangian kekuasaan struktur politik dan kelembangaan dalam negeri.

\section{Pengaruh Zakat, Infaq dan Shadaqah (ZIS) terhadap kemiskinan}

Zakat,infaq dan shadaqah merupakan salah satu sumber dari penerimaan negara yang penting, selain hal tersebut ZIS merupakan suatu alat bantu dari bantuan sosial mandiri yang menjadi suatu kewajiban moral bagi orang kaya untuk membatu yang miskian, sehingga kemiskinan dan kemelaratan dapat terhapuskan dari masyarakat.

Al- Qardhawi (2002) mengatakan bahwa tujuan mendasar dari ibadah zakat adalah untuk menyelesaikan berbagai macam persoalan sosial seperti halmya pengangguran, kemiskinan dan lainlain. Sistem distribusi pada zakat merupakan solusi terhadap suatu persolan-persoalan tersebut dengan memberikan suatu bantuan kepada orang yang miskin tanpa memandang etnis, ras, warna kulit dan atributatribut keduniawian lainnya.

Membayar zakat merupakan wujud pelaksanaan ibadah guna menghindarkan diri dari kekufuran sekaligusuntuk mengeliminir munculnya sifat iri dan dengki ketika si miskin melihat kelompok masyarakat kaya. Sejumlah penelitian juga telah menjelaskan adanya korelasi zakat dan keadilan sosial yaitu mendeskripsikan Islam mensyariatkan zakat dengan tujuan meratakan jaminan sosial (keadilan sosial). Karena zakat adalah dana yang dipungut dari si kaya untuk diberikan kepada si miskin. Jadi tujuan zakat sangat jelas untuk mendistribusikan harta di masyarakat dengan cara sedemikan rupa sehingga tidak seorang pun umat Islam yang tinggal dalam keadaan miskin dan menderita (Baehaqi 2005). Oleh karenanya apabila ketaatan membayar zakat ini berlangsung komperehensif maka zakat akan dapat menjadi potensi ekonomi sebagai sumber dana pembangunan bagi terbangunnya sarana dan prasarana sosial ekonomi yang dibutuhkan umat. 


\section{Jurnal Ilmiah Ekonomi Islam, 7(02), 2021, 956}

Bahkan sangat mungkin zakat dapat didayagunakan untuk mendukung program-program bagi peningkatan kualitas sumber daya manusia.

\section{Pengaruh IPM terhadap kemiskinan}

Indeks pembangunan manusia merupakan terdapat tiga indikator komposit yang digunakan untuk dapat mengukur pencapaian rata-rata suatu negara dalam pembangunan manusia ialah: lama hidup, pendidikan dan standar hidup yang diukur dengan pengeluaran perkapita yang telah disesuaikan menjadi paritas daya beli. Maka dengan demikian melakukan investasi pendidikan akan mampu meningkatkan suatu kualitas sumber daya manusia yang diperhatikan dengan meningkatnya suatu pengetahuan dan keterampilan dari seseorang.

Seakin tingkat pendidikan seseorang, maka pengetahuan dan keahlian akan meningkat sehingga akan mendorong suatu peningkatan produktivitas kerjanya ketika terjadi suatu peningkatan pada produktivitas otomatis akan dapat meningkatkan pendapatannya dan secara tidak langsung mengurangi kemiskinan. Perusahaan akan memperoleh hasil yang akan lebih banyak didapat dengan mempekerjakan tenaga kerja dengan produktivitas yang tinggi, sehingga suatu perusahaan akan dapat memberikan gaji yang lebih tinggi kepada karyawan atau yang bersangkutan. Di sektor informal seperti halnya pertanian,peningkatan keterampilan dan keahkian tenaga kerja akan mampu untuk meningkatkan hasil pertanian karena tenaga kerja yang terampil mampu bekerja lebih efisien. Pada akhirnya seseorang yang memiliki produktivitas yang tinggi akan dapat memperoleh kesejahteraan yang lebih baik, yang diperintahkan melalui peningkatkan pendapatan maupun konsumsinya. Rendahnya produktivitas pada kaum miskin dapat disebabkan oleh rendahnya akses mereka untuk memperoleh pendidikan (Rasidin $\mathrm{K}$ dan Bonar , 2004)

Pembangunaan manusia di indonesia identik dengan pengurangan kemiskina (saputra, 2011). Investasi pada bidang pendidikan kesehatan akan lebih berarti bagi penduduk miskin dibandingkan penduduk tidak miskin, karena bagi penduduk miskin aset utama ialah tenaga kasar, adanya suatu fasilitas pendidikan dan kesehatan akan dapat membantu untuk meningkatkan suatu produktivitas yang pada akhirnya akan meningkatkan suatu pendapatan.

\section{Pengaruh Inflasi terhadap kemiskinan}

Inflasi adalah kecendrungan harga-harga barang naik secara terus menerus. Kenaikan harga-harga barangbersifat menyeluruh, jika hanya beberapa jenis barang saja maka tidak dikatan inflasi kecuali jika kenaikan harga pada satu barang meluas dan berimbas pada kenaikan barang-barang lainnya ( Boediono, 2008)

Inflasi merupakan salah satu indikator makroekonomi yang sangat mempengaruhi aktivitas perekonoian. Inflasi yang terlalu tinggi akan menganggu kestabilan pereokonomian dan akan menurunkan nilai mata uang yang pada akahirnya akan menekan daya beli masyarakat. Sebaliknya, inflasi yang terlalu rendah merupakan indikator daya beli masyarakat yang akan menekan laju pertumbuhan ekonomi. (Sukirno, 2013: 339)

Menurut Keynes inflasi terjadi karena suatu masyarakat ingin hidup diluar batas kemampuan ekonominya. Maka dengan kata lain proses perebutan bagian rezeki diantara kelompok-kelompok sosial yang menginginkan bagian yang lebih besar dari pada yang dapat disediakan masyarakat sehingga proses perebutan ini pada akhirnya diterjemahkan menjadi keadaan dimana permintaan masyarakat akan barangbarang selalu melebihi jumlah barang-barang yang tersedia (inflationary gap).

\section{METODE PENELITIAN}

Pada penelitian ini jenis dan sumber datayang digunakan aialah data sekunder yang berasal dari Badan Pusat Statistik (BPS) dan Badan Amil Zakat Nasional (BAZNAS). Adapun data sekunder yang digunakan daa penelitian ini adalah data cross setion dari 34 Provensi yang ada di Indonesia dan data time series dari tahun 2016 sampai dnegan tahun 2019 atau lebih sering disebut dengan data Panel.

Metode analisis yang digunkan dalam penelitian ini merupakan metode analisis data panel sebagai alat untuk pengolahan data menggunakan Eviews9. Metode analisis data panel ialah kombinasi antara deret waktu (time series) dengan analisis deret hitung (cross section), (Widarjono, 2013). Terdapat bentuk regresi untuk data panel pada penelitian ini adaah sebagai berikut:

$$
\text { TK }=\beta_{0}+\beta_{1} \text { ZIS }+\beta_{2} I P M+\beta_{3} I N F+\mu
$$

Keterangan :

$\begin{array}{ll}\text { TK } & =\text { Tingkat Kemiskinan } \\ \text { ZIS } & =\text { Zakat Infaq dan Shadaqah } \\ \text { IPM } & =\text { Indeks Pembangunan Manusia } \\ \text { INF } & =\text { Tingkat Inflasi } \\ \beta_{0} & =\text { Konstanta } \\ \beta_{1} \beta_{2} \beta_{3} & =\text { Koefisien regresi berganda } \\ \mu & =\text { variabel penganggu }\end{array}$




\section{Jurnal Ilmiah Ekonomi Islam, 7(02), 2021, 957}

Dalam estimasi model analisis regresi data panel dapat dilakukan dengan tiga pendekatan ialah dengan menggunakan Commond Effect Model, Fixed Effect Model dan Rendom Effect Model. (Wijayanto, 2013)

\section{HASIL DAN PEMBAHASAN}

Tabel. 1

Hasil Pengujian Uji Chow Test

Redundant Fixed Effects Tests

Equation: Untitled

Test cross-section fixed effects

\begin{tabular}{lrrc}
\hline \hline Effects Test & Statistic & d.f. & Prob. \\
\hline Cross-section F & 58.208133 & $(33,99)$ & 0.0000 \\
$\begin{array}{l}\text { Cross-section Chi- } \\
\text { square }\end{array}$ & 410.130818 & 33 & 0.0000 \\
\hline \hline
\end{tabular}

Pada hasil pengujian yang dilakukan dengan menggunakan uji chow diatas diperoleh nilai probabilitasnya chi- squarenya sebesar $0.000<\alpha 5 \%$, hal ini menunjukkan bahwaH0 ditolak dan $\mathrm{H} 1$ diterima. Jadi kesimpulan dari hasil tersebut diperoleh dengan model fixed effect yang lebih cepat untuk digunakan dibandingkan dengan common effect models.

\section{Tabel. 2}

\section{Hasil Pengujian Uji Hausman Test}

Correlated Random Effects - Hausman

Test

Equation: Untitled

Test cross-section random effects

\begin{tabular}{lrrr}
\hline \hline & Chi-Sq. & Chi-Sq. & \\
Test Summary & Statistic & d.f. & Prob. \\
\hline \hline Cross-section random & 0.000000 & 3 & 1.0000 \\
\hline \hline
\end{tabular}

* Cross-section test variance is invalid. Hausman statistic set to zero.

Dari hasil pengujian pada uji hausman dapat dilihat bahwa probabilitas yang dihasilkan yakni sebesar 1.0000 yang artinya lebih besar dari alfa 0,05 (1.0000 >0,05\%. Maka dengan ini H1 diterima dan H0 ditolak, sehingga dapat disimpulkan bahwa hasil dari estimasi terakhir model yang tepat untuk digunkan ialah dengan model Random Effect.

Tabel.3 Uji Langrange Multiplier Test

Lagrange Multiplier Tests for Random Effects

Null hypotheses: No effects

Alternative hypotheses: Two-sided (Breusch-Pagan) and one-sided

(all others) alternatives

\begin{tabular}{lcll}
\hline \hline \multicolumn{4}{c}{ Test Hypothesis } \\
\hline \hline & Cross-section & \multicolumn{1}{c}{ Time } & Both \\
\hline Breusch- & & & \\
Pagan & 178.1829 & 1.799400 & 179.9823 \\
& $(0.0000)$ & $(0.1798)$ & $(0.0000)$ \\
\hline \hline
\end{tabular}

Uji langrange merupakan pengujian statistik untuk memilih apakah model common effect atau Random effect yang paling tepat untuk digunakan. Pada hasil uji langrange diatas menunjukkan hasil chisquares dengan penelitian probabilitas 0,000 . Nilai probabilitas yang diperoleh lebih kecil dari 0,05 sehingga dengan ini $\mathrm{H} 0$ ditolak dan $\mathrm{H} 1$ diterima. Maka dari hasil penelitian tersebut menunjukkan bahwa mode yang tepat untuk digunakan adalah random effect.

Dari hasil pengujian chow test, hausman test dan lagrenge multiplier menunjukkan bahwa estimasi yang paling tepat untuk digunakan dalam penelitian ini ialah dengan estimasi Random Effect Model (REM).

\section{Tabel. 4}

\section{Hasil Estimasi Random Effect Models}

Dependent Variable: KEMISKINAN

Method: Panel EGLS (Cross-section random effects)

Date: $11 / 27 / 20$ Time: $14: 48$

Sample: 20162019

Periods included: 4

Cross-sections included: 34

Total panel (balanced) observations: 136

Swamy and Arora estimator of component variances

\begin{tabular}{crrrr}
\hline \hline Variable & Coefficient & Std. Error & t-Statistic & Prob. \\
\hline \hline $\mathrm{C}$ & 31290705 & 3041794. & 10.28693 & 0.0000 \\
ZIS & $4.87 \mathrm{E}-05$ & $3.50 \mathrm{E}-06$ & 13.88428 & 0.0000 \\
$\mathrm{IPM}$ & -154.7464 & 358.7131 & -0.431393 & 0.6669 \\
INFLASI & 552350.2 & 718674.5 & 0.768568 & 0.4435 \\
\hline \hline \multicolumn{5}{c}{ Effects Specification } \\
& S.D. & Rho \\
\hline \hline Cross-section random & 8333789. & 0.9365 \\
Idiosyncratic random & 2169666. & 0.0635 \\
\hline \hline
\end{tabular}

Weighted Statistics

\begin{tabular}{lll} 
& \multicolumn{2}{c}{ Mean dependent } \\
R-squared & $0.679005 v a r$ & 5437972
\end{tabular} Adjusted

R-squared 0.671709 S.D. dependent var 3772480. S.E. of $6.17 \mathrm{E}+1$ regression 2161505. Sum squared resid F-statistic 93.07367 Durbin-Watson stat 1.221429 Prob(F-

statistic) $\quad 0.000000$

\begin{tabular}{|c|c|c|c|}
\hline \multicolumn{4}{|c|}{ Unweighted Statistics } \\
\hline & & Mean dependent & 4212747 \\
\hline R-squared & $0.120799 \mathrm{v}$ & & \\
\hline resid & $9.51 \mathrm{E}+15$ & Durbin-Watson s & 0.079217 \\
\hline
\end{tabular}


Uji Koefisien Regresi secara bersama-sama (Uji F)

Pada tabel 3. Diketahuai bahwa nilai f hitung statistik sebesar 93.07367 dan probabilitasnya sebesar 0,000. Pada tingkat singnifikansi $\alpha$ : 5\% maka koefisien $\mathrm{f}$ statistik pada hasil uji tersebut signifikan karena $\mathrm{p}=0,000<0,05$. Berdasarkan pada hasil pengujian di atas maka dapat disimpulkan bahwa, secara bersama atau simultan mengatakan bahwa Zakat, infaq, shodaqah (ZIS), Indek Pembangunan Manusia Dan Inflasi berpengaruh terhadap kemiskinan sehingga hipotesis 1 dalam penelitian ini terbukti.

\section{Uji Koefisien Regresi Secara Parsial (Uji t)}

\begin{tabular}{crrrr}
\hline \hline Variable & Coefficient & Std. Error & t-Statistic & Prob. \\
\hline \hline C & 31290705 & 3041794. & 10.28693 & 0.0000 \\
ZIS & $4.87 \mathrm{E}-05$ & $3.50 \mathrm{E}-06$ & 13.88428 & 0.0000 \\
IPM & -154.7464 & 358.7131 & -0.431393 & 0.6669 \\
INFLASI & 552350.2 & 718674.5 & 0.768568 & 0.4435 \\
\hline \hline
\end{tabular}

Pada uji t bertujuan untuk mengetahuai pengaruh variabel indipenden yaitu ZIS, IPM, INFLASI terhadap variabel dependen yakni Kemiskinan. Dari output diatas dapat dilihat dari nilai probability dari masing-masing variabel bebas yang digunakan. Dari oautput tersebut diperoleh hasil bahwa koefisien regresi variabel ZIS sebesar 4,87 dan probabilitas 0,0000. Pada tingkat signifikansi $\alpha: 5 \%$ maka koefisien regresi karena $p=0,0000>0,05$. dan IMP diperoleh hasil koefisien regresi sebesar $-154,7464$ dan probabilitas 0,6669 . Pada tingkat signifikansi $\alpha$ : $5 \%$ maka koefisien regresi karena $\mathrm{p}=0,6669>0,05$. memiliki nilai probability yang lebih besar dari alfa $(0,05)$ dari hasil data tersebut menunjukkan bahwa IPM memiliki pengaruh terhadap variabel $Y$ (Kemiskinan ). Sedangkan pada variabel inflasi diperoleh hasil koefisien sebesar 5523502 Pada tingkat signifikansi $\alpha: 5 \%$ maka koefisien regresi karena $\mathrm{p}=0,4435>0,05$. hal tersebut juga menunjukkan bahwa tidak memiliki pengaruh terhadap variabel Y (Kemiskinan). Dari hasil tersebut menunjukkan hal yang sama seperti yang telah dilakukan oleh khariril 2018 yang mengasilkan inflasi memiliki pengaruh yang posfitif terhadap kemiskinan. Begitu juga yang penelitian yang dilakukan oleh (Yolanda,2017) mendapatkan hasil yang signifikan dan positif inflasi terhadap kemiskinan. Hasil penelitian yang menyatakan bahwa inflasi dapat untuk mempengaruhi kemikinan ialah (shahidur,2012) mereka mengemukakan bahwa meskipun dalam kebanyakan kasus inflasi menunjukkan korelasi yang positif dan signifikan secara statistik dengan kemikinan, namun dalam hal negara yang berpenghasilan rendah, hubungan antara inflasi dan kemiskinan adalah negatif secara signifikan pada spesifikasi tertentu. Hasil studi InHazoor (Muhammad Sabir dan SafdarHussain Tahir 2012) mengungkapkan inflasi berdampak positif terhadap kemiskinan di Pakistan (1981-2010). (Eliana Cardoso (1992) dalam artikelnya yang berjudul "Inflasi dan Kemiskinan", dengan wilayah penelitian di tujuh negara Amerika Latin (Argentina, Kolombia, Kosta Rika, Chili, Meksiko, Peru dan Uruguay) dengan data dari tahun 1977 hingga 1989, dengan menggunakan metode regresi linier, diperoleh kesimpulan bahwa inflasi menyebabkan kemiskinan pada umumnya melalui upah riil (upah riil), bukti empiris menunjukkan bahwa kenaikan upah lebih lambat daripada kenaikan harga karena inflasi di Amerika Latin. (Sudarlan, 2015) mengatakan bahwa inflasi berdampak positif dan signifikan terhadap angka kemiskinan dan tidak berpengaruh pada kesenjangan kemiskinan dan keparahan kemiskinan.

\section{Uji Koefisien determinan (Uji R2)}

Pada uji Adjusted R2 ditunjukkan menilai seberapa besar suatu kemampuan variabel independen menjelaskan variabel dependen. Pada penelitain ini, koefisien yang digunakan adalah determinasi yang telah disesuaikan Adjusted R2. Hal tersebut dikarenakan R2 merupakan suatu koefisien yang telah dikoreksi sehingga akan naik atau turun seiring dengan penambahan variabel baru dalam model.

Berdasarkan pada hasil regresi dengan menggunakan rendom effect mode yang terlihat pada tabel, diketahui bahwa nialai koefisien determinasi sebesar 0,679005 memiliki arti bahwa ZIS, IPM dan Inflasi berpengaruh terhadap tingkat kemiskinan sebesar 67, $9 \%$. Sedangkan sisanya 30,3\% dipengaruhi oleh hal yang lain yang tidak di analisis pada penelitian ini.

\section{PENUTUP}

Pada penelitian yang telah dilakukan dengan uji persamaan model dengan menggunakan commen effect model, fixed effect model dan random effect model, uji chow, uji hausman dan uji lagrang, uji regresi data panel dengan mengguanakan random effect model. Dari hasil penlitian tersebut menunjukkan bahwa ZIS, IMP dan INFLASI menunjukkan bahwa ZIS berpengaruh signifikan terhadap pengentasan kemiskinan sedangkan IPM dan 
Inflasi berpengaruh tidak berpengaruh terhadap pengentasan kemiskinan. Berdasarkan pada hasil regresi dengan menggunakan rendom effect mode yang terlihat pada tabel, diketahui bahwa nilai koefisien determinasi sebesar 0,679005 memiliki arti bahwa ZIS, IPM dan Inflasi berpengaruh terhadap tingkat kemiskinan sebesar $67,9 \%$. Sedangkan sisanya $30,3 \%$ dipengaruhi oleh hal yang lain yang tidak di analisis pada penelitian ini.

\section{DAFTAR PUSTAKA}

Ahmed, Fahme Mohd Ali, Zakariah Abd Rashid, Faud Johari. Dkk. 2015. The Effectiveness of Zakat in Reducing Poverty Incident: An Analysis in Kelaten, Malaysia. Asian Social Science.Vol 11 No.21. DOI. 10.5539/ass.v11n21p355

Basari, Faisal dan jossy Moeis dan Yando Zakaria. 1995. Penanggulangan Kemiskinan Di Indonesia. Dalam Faisal Basari, Perekonomian Indonesia Menjelang Abad XXI. P. 177

Boediono. 2008. Ekonomi Moneter. Seri Sinopsis Pengantar ilmu Ekonomi No.5 (Edisi 3 ed). Yogyakarta: BPFE

Elizabeth A.S.2007. The Human Development Index: A History. Political Economy Research Intitute,University of Massachusetts,Amherst.

Easterly, W.and Fisher, S. 2001. Inflation and poor. Journal of Money, Credit and Banking, 33(2).

Elizabeth A.S.2007. The Human Development Index: A History. Political Economy Research Intitute,University of Massachusetts,Amherst.

Ikhsan, Khairil Ihsan. 2018. Analisis Pengaruh UMP, INFLASI dan Pengangguran Terhadap Kemiskinan di Provensi Aceh. Jurnal Pembangunan Fakultas Ekonomi dan Bisnis Unsyiah. Vol. 3 No. 3

Joko,S. 2014. Impact of Economic Growth, Inflation and Minimum Wage on Poverty in Java. Media Ekonomi and Teknologi Informasi, 22.

Karim, Adiwarman A. 2011. Bank Islam Analilsis Fiqih dan Keuangan, edisi 4. Jakarta : PT. Rajawali Pers

Khoutem Ben Jedidia \& Khouloud Guerboui. 2020. Effects of Zakat on the Economic Growth in selected Isamic Countries : empirical evidence. International Journal of Development Issues. 1446-8956. DOI 10.1108/IJDI-05-2020-0100
Made, Kembar Sri Budhi. 2013. Analisis Faktorfaktor yang Berpengaruh Terhadap Pengentasan Kemikinan di Bali: Analisis FEM Data Panel. Vol. 6 No.1

Makiko,I.H. 2014. The Human Development Index: Asearchfor a measure of human values. Dissertation, Published by ProQuest LLC.

Muhammad, Seed Meo, Vina Javad Khan dkk. 2018. Asymmetric impact of infation and unemployment on poverty in pakistan: new evidence from asymmentric ARDL cointegration.Journal Of Social Work and Developmen.

Oye,D.2012. Inflasi dan Kemiskinan di Nigeria : Peran ICT di Kemiskinan Pengurangan. Universitas Jurnal Manajemen dan Ilmu Sosial. 2, 21-28

Powers, E.T. 1995. Inflation, Unemployment and Revisited. Federal Bank of Cleveland, Economic Commentary

Ridwan, Muhtadi. Laila M. Pimada, Nur aswani. 2019. Zakat Distribution and Macroeconomic Performance: Empirical Evidence of Indonesia. International Journal of Supply Chain Management Vol. 8 No. 3

Sudarlan,2015. Contribution of Human Development Index on Per Capita Income Growth and Poverty Alleviation in Indonesia. International Journal of Scientific \& Technology Research

Sukirno. 2013. Makroekonomi Teori Pengantar. Jakarta: Rajawali Pers.

Shahidur,R.,Talukdar, M.2012. The Effect of Inflation on Poverty in Developing Countries: A Panel Data Analysis.Thesis of Texas Tech University

Sasadegh Bakhtiari, Hossein Meisami. 2010. An empirical investigation of the effects of health and eduction on income distribution and poverty in Islamic Countries. International Journal of Social Economis. Vol. 37 No. 4. DOI 10.1108/03068291011025255

Sudarlan,2015. Contribution of Human Development Index on Per Capita Income Growth and Poverty Alleviation in Indonesia. International Journal of Scientific \& Technology Research

Todaro, Michael. 1994, Pembangunan Ekonomi di Dunia Ketiga, Edisi Kedua, Terjemahan Haris Munandar. Jakarta: Erlangga. 
Todaro, Michael. 2000, Pembangunan Ekonomi di Dunia Ketiga, Edisi Kedua, Terjemahan Haris Munandar. Jakarta: Erlangga.

Wongdesmiwati. (2009). Pertumbuhan Ekonomi dan Pengentasan Kemiskinan di Indonesia : Analisis Ekonometrika .Retrieved November 28, 2017.

Wulandari, F. H. (2015). Pengaruh Pertumbuhan Ekonomi, Inflasi, Pengangguran, dan Pendidikan Terhadap Kemiskinan di Indonesia Tahun 2008 2012. E-Journal UAY.

Yanti, N. (2011). Pengaruh Pertumbuhan Ekonomi, Inflasi, dan Tingkat Kesempatan Kerja Terhadap Tingkat Kemiskinan di Indonesia Tahun 1999 2009. http://repository.upnyk.ac.id/1662/, 1-57.
Yasir, Aziz. Fadillah Mansor, Shujaa Waqr dan Luqman Haji Abdullah. 2020. The nexus between zakat and poverty reduction, is the effective ultilization of zakat necessary for achieving SDGs: A multidimensional poverty index approach. DOI:10.1111/aswp.12212

Yolanda. 2017. Analysis of Fectors Affecting Inflation and ist Impact on Human Development Index and Poverty in Indonesia. Lecturer of Econommic.Borobudur University, Indonesia. Vol. XX, pp. 38-56

www. bps.go.id diakses pada 20 November 2020 www. BAZNAS.go.id diakses pada 20 November 2020 